\title{
Sparc-Like Protein 1 Is a New Marker of Human Glioma Progression
}

Andrei Turtoi, ${ }^{*}, \dagger$ Davide Musmeci, ${ }^{\dagger},{ }^{\ddagger}$ Antonio Giuseppe Naccarato, ${ }^{\S}$ Cristian Scatena, ${ }^{\S}$ Valerio Ortenzi, ${ }^{\S}$ Robert Kiss, ${ }^{\prime \prime}$ Daniela Murtas, ${ }^{\perp}$ Georgios Patsos, ${ }^{\dagger}$ Gabriel Mazzucchelli, ${ }^{\ddagger}$ Edwin De Pauw, Generoso Bevilacqua, ${ }^{\S}$ and Vincent Castronovo ${ }^{\dagger}$

${ }^{\dagger}$ Metastasis Research Laboratory, GIGA-Cancer, University of Liege, Bat. B23, Liege, Belgium

${ }^{\ddagger}$ Laboratory of Mass Spectrometry, University of Liege, Bat. B6C, Liege, Belgium

${ }^{\S}$ Division of Surgical, Molecular and Ultrastructural Pathology, University Hospital of Pisa, Pisa, Italy

"Laboratory of Toxicology, Faculty of Pharmacy, Université Libre de Bruxelles, Brussels, Belgium

${ }^{\perp}$ Department of Biomedical Sciences, Section of Cytomorphology, University of Cagliari, Cagliari, Italy

\section{Supporting Information}

ABSTRACT: High-grade gliomas (glioblastomas) are the most common and deadly brain tumors in adults, currently with no satisfactory treatment available. Apart from de novo glioblastoma, it is currently accepted that these malignancies mainly progress from lower grade glial tumors. However, the molecular entities governing the progression of gliomas are poorly understood. Extracellular and membrane proteins are key biomolecules found at the cell-to-cell communication interface and hence are a promising proteome subpopulation that could help understand the development of glioma. Accordingly, the current study aims at identifying new protein markers of human glioma progression. For this purpose, we used glial tumors generated orthotopically with T98G and U373 human glioma cells in nude mice. This setup allowed also to discriminate the protein origin, namely, human (tumor) or mouse (host). Extracellular and membrane proteins were selectively purified using biotinylation followed by streptavidin affinity chromatography. Isolated proteins were digested and then identified and quantified employing 2Dnano-HPLC-MS/MS analysis. A total of 23 and 27 upregulated extracellular and membrane proteins were identified in the T98G and U373 models, respectively. Approximately two-thirds of these were predominantly produced by the tumor, whereas the remaining proteins appeared to be mainly overexpressed by the host tissue. Following extensive validation, we have focused our attention on sparc-like protein 1. This protein was further investigated using immunohistochemistry in a large collection of human glioma samples of different grades. The results showed that sparc-like protein 1
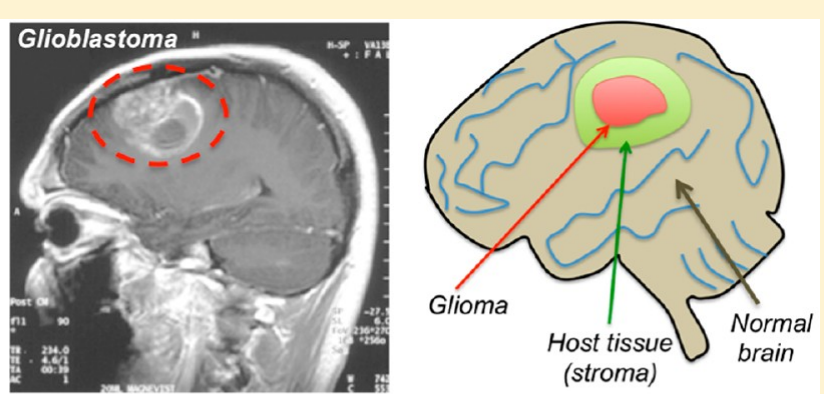

SPRL1_MOUSE
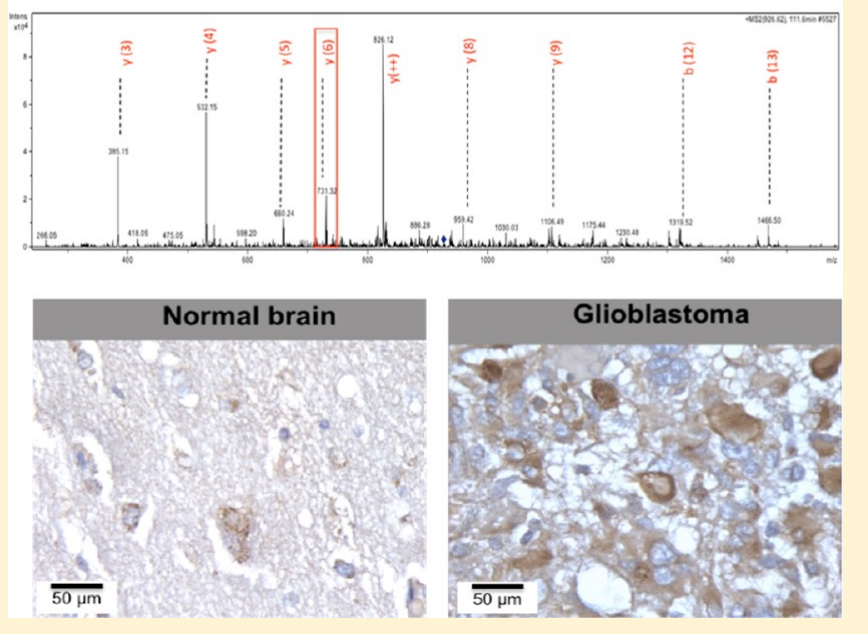
expression correlates with glioma grade, suggesting the possible role for this protein in the progression of this malignancy. KEYWORDS: glioblastoma, cancer, proteomics, biomarkers

\section{INTRODUCTION}

Brain nervous tissue consists of neuronal (neurons) and nonneuronal (glial) cells. In contrast to neurons, glial cells retain the capability to undergo mitosis, in particular at sites of brain damage. ${ }^{1,2}$ Astrocytes are a subpopulation of glial cells, mainly involved in anchoring neurons to the blood supply and controlling their chemical environment by removing excess ions and neurotransmitters. ${ }^{1}$ This subpopulation of glial cells gives origin to a type of brain tumor commonly known as astrocytoma. ${ }^{3}$ Astrocytoma can develop in patients of any age, mainly in the cerebrum, and rarely gives rise to metastasis outside the skull. The World Health Organization (WHO) considers different subtypes of astrocytoma according to their

Received: June 24, 2012

Published: August 21, 2012 
Mouse brain tumor xenografts

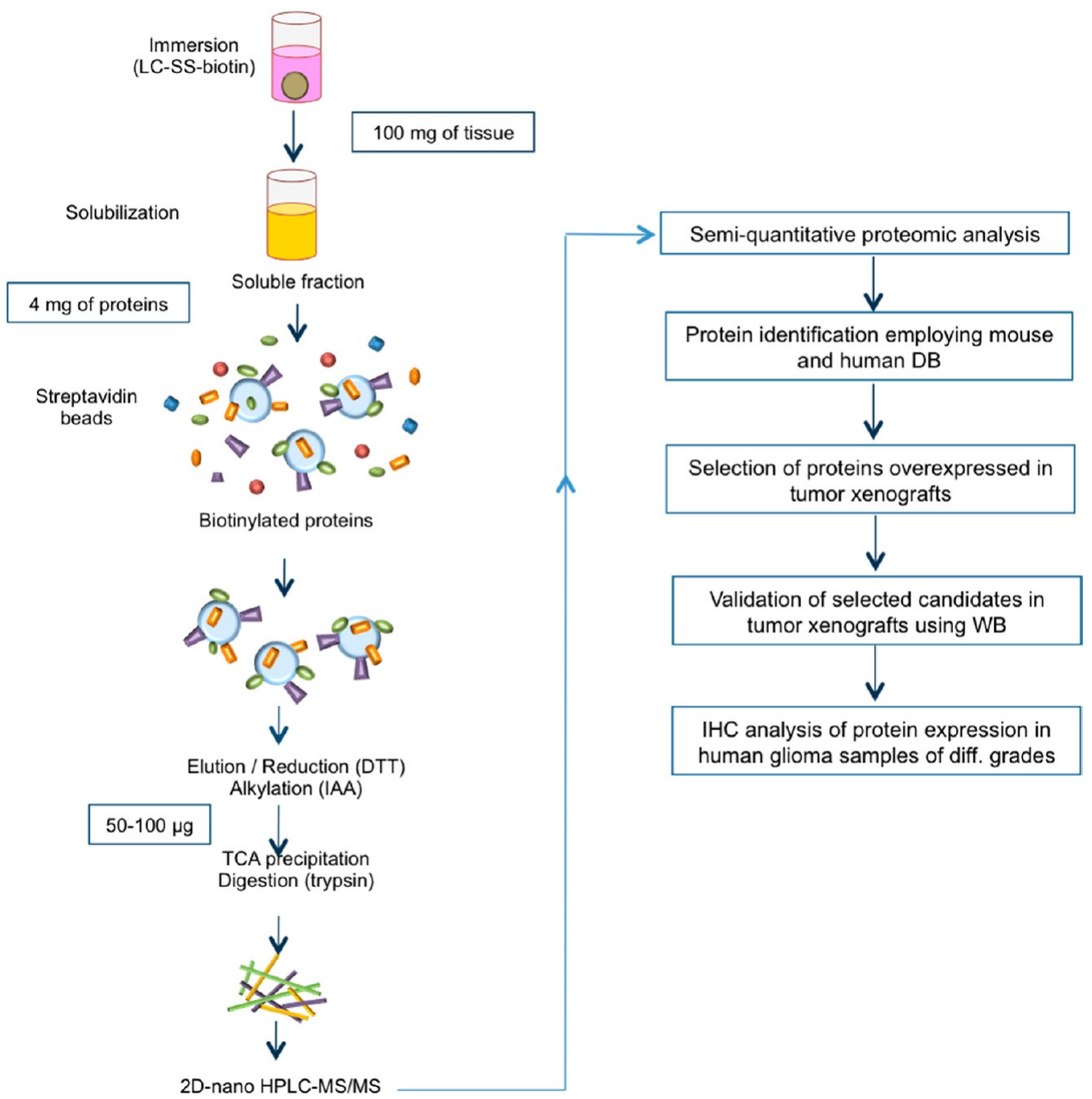

Figure 1. Workflow of the differential proteomic analysis. The experiment commences with tumor generation and is followed by labeling of the accessible proteins using modified biotin reagent. Biotinylated proteins are purified using streptavidin beads and digested with trypsin into peptides. The peptides are than sequenced using 2D-nano-HPLC-MS/MS. Subsequently, the peptide sequences are compared with existing mouse and human databases. Selected proteins are than validated using WB and IHC in mouse bearing tumors as well as relevant human samples.

histological degree of differentiation and their morphological characteristics of aggressiveness. ${ }^{4}$ According to their proliferative activity, degree of atypia, and infiltrative behavior astrocytomas are classified as (i) pilocytic astrocytoma or WHO grade I (a benign and rare pediatric brain tumor), (ii) diffuse astrocytomas or WHO grade II (low proliferation rate, low grade of atypia, infiltration of adjacent structures), (iii) anaplastic astrocytomas or WHO grade III (high proliferation rate, high grade of atypia, diffuse infiltration of the nervous tissue), and (iv) glioblastoma multiforme (GBM) or WHO grade IV (the most aggressive type, with extreme anaplasia, very high proliferation rate, diffuse infiltration of the nervous tissue, prominent neo-angiogenesis, frequent areas of necrosis).,5 GBM is the most common type of primary brain tumors in human adults, ${ }^{6}$ with life expectancy that rarely exceeds 14 months. ${ }^{5}$ Current therapies are based on surgical resection of the tumor followed by local radiation and adjuvant chemotherapy. ${ }^{6}$ The ability of GBM cells to migrate through the brain parenchyma ${ }^{8}$ makes them an elusive target for effective treatment. Current research is focused on developing suitable (molecular) targeted therapies that could treat GBM more effectively. Most therapies in clinical trials focus either on blocking the epithelial growth factor receptor (EGFR) of the tumor cells or on inhibiting angiogenesis via interfering with vascular endothelial growth factor receptor (VEGFR) and platelet derived growth factor receptor (PDGFR). ${ }^{9-12}$ However, because of its particular tissue features, effective GBM treatment is likely to require a more specifically tailored type of therapy. Therefore it is of high interest to identify novel proteins involved in the pathology of gliomas, offering new putative targets for drug discovery and more efficient diagnosis. In this respect a particular subclass of proteins, found at the exterior of the cell (cell membrane or extracellular matrix) and herein further referred as accessible, is particularly appealing for identification of novel protein targets. Such accessible proteins bear the potential to be easily and efficiently reached by systemically administered compounds (e.g., antibodies coupled to toxic coumponds or imaging molecules). Furthermore, from a biological point of view this subclass of proteins is located at the interface of cell-cell and cell-extracellular matrix 
interaction, underlying the importance of their role in fundamental cancer processes such as invasion and migration. ${ }^{13}$

Today there are no studies characterizing the membrane and extracellular proteins in GBM. The present study is filling this void using innovative proteomic technologies and suitable murine in vivo models. In this work we present an extensive proteomic analysis, offering an original repertoire of modulated accessible proteins of two astrocytic human cell lines (U373 and T98G) xenografted in mouse brain. The two cell lines have previously been reported to display distinctive in vivo features of anaplastic astrocytoma and glioblastoma tumors. ${ }^{14-18}$ This model offers one interesting advantage, namely, the option of discriminating proteins produced by the tumor cells (human) from those produced by the stroma (murine). At a preanalytical level, we exploit a previously developed ex vivo biotinylation method for the selective enrichment of membrane and extracellular proteins. ${ }^{19,20}$ This specific group of proteins is subsequently identified and semi-quantified using mass spectrometry.

The results highlight a repertoire of known and novel proteins in the context of human glioma. One of these, sparclike protein 1 (SPRL1 [gene name: SPARCL1]), is to our knowledge not reported to be associated with high-grade gliomas. SPRL1 overexpression in brain tumors of xenografted animals as well as in a large collection of human gliomas of different grades was confirmed by validation studies employing WB and IHC. Importantly, the expression pattern of SPRL1 correlated well with the progression stage of human glioma.

\section{MATERIALS AND METHODS}

Unless otherwise specified all the reagents used in the present study were obtained from Sigma Aldrich Co. (St. Louis, MO, USA). The in vivo experiments were performed on the basis of authorization of the Animal Ethics Committee of the Federal Department of Health, Nutritional Safety and the Environment (Belgium).

\section{Cell Culture and Animal Models}

Human U373 (ATCC code HTB-17) and T98G (ATCC code CRL1690) GBM cell lines were obtained from the American Type Culture Collection (ATCC; Manassas, VA, USA) and maintained as detailed previously. ${ }^{21}$ Briefly, cells were cultured at $37{ }^{\circ} \mathrm{C}$ in Falcon plastic dishes (Gibco, Nunc, Belgium) containing Eagle minimal essential medium (MEM; Gibco, Nunc, Belgium) supplemented with $10 \%$ fetal calf serum (FCS), a mixture of glutamine $(0.6 \mathrm{mg} / \mathrm{mL}$ final concentration (FC); Gibco, Nunc, Belgium), penicillin (200 IU/mL final concentration; Gibco, Nunc, Belgium), streptomycin (200 IU/ $\mathrm{mL}$ FC; Gibco, Nunc, Belgium) and $0.1 \mathrm{mg} / \mathrm{mL}$ gentamycin (Gibco, Nunc, Belgium). The FCS was heat inactivated for $1 \mathrm{~h}$ at $56{ }^{\circ} \mathrm{C}$.

In vivo mice orthotopic xenografts were obtained by injecting $1 \times 10^{6}$ of either T98G or U373 cells into the left temporal lobes of nude mice (6-week-old female nu/nu mice of 21-23 g; Janvier, Le Genest-Saint-Isle, France) as described previously. ${ }^{21}$ A set of 9 mice were injected with each of the two cell lines, while 9 more were injected with PBS and used as mock control. Mice were then sacrificed 5 weeks after the graft, and left hemispheres were collected. Six animals per condition were used for biotinylation and MS analysis, whereas three of each were kept for $\mathrm{WB}$ and IHC based validation.

\section{Tissue Biotinylation and Protein Extraction}

The biotinylation procedure was performed as detailed previously (Figure 1). ${ }^{19}$ Briefly, the brains were sliced and soaked into freshly prepared EZ-link Sulfo-NHS-SS biotin (1 $\mathrm{mg} / \mathrm{mL}$, Pierce, Thermo Scientific, USA) in PBS ( $\mathrm{pH} 7.4$ ) at 37 ${ }^{\circ} \mathrm{C}$ for $20 \mathrm{~min}$. This was followed by a $5 \mathrm{~min}$ quenching step using $50 \mathrm{mM}$ Tris- $\mathrm{HCl}(\mathrm{pH} 7.4)$ at $37{ }^{\circ} \mathrm{C}$. The samples were then rinsed with PBS ( $\mathrm{PH}$ 7.4) and snap-frozen in liquid nitrogen. Following this, $100 \mathrm{mg}$ of tissue were pulverized using mikro-dismembrator (B. Braun Biotech, Melsungen, Germany) and dissolved in $1 \mathrm{~mL}$ of lysis buffer (PBS $50 \mathrm{mM}, \mathrm{NaCl} 0,5 \mathrm{M}$, NP40 1\%, DOC 0,5\%, SDS $1 \%$ ) containing a protease inhibitor cocktail (Protease Inhibitor Cocktail 100x, Thermo Fisher Scientific, Waltham, MA, USA) and not oxidized glutathione to preserve the disulfide bond of the Sulfo-NHS-SS biotin reagent. Subsequently, the samples were sonicated $(2 \times 30 \mathrm{~s})$ using a 2 $\mathrm{mm}$ microprobe (Vibra-Cell 75022, Bioblock Scientific, Illkirch, France; Sonication parameters: sample temperature $=4{ }^{\circ} \mathrm{C}$, amplitude $=30$ and pulser $=2 \mathrm{~s}$ ). Finally, protein concentration was determined using the BCA protein assay reagent kit (Pierce, Thermo Fisher Scientific, Waltham, MA, USA). In order to isolate the biotinylated proteins, the necessary amount of streptavidin-sepharose resin (Amersham Biosciences, 150 $\mu \mathrm{L} / \mathrm{mg}$ of total protein extract) was equilibrated by five washes in buffer A ( $1 \%$ NP40 and $0.1 \%$ SDS in PBS $50 \mathrm{mM}$ ). Following this, the total protein lysate and streptavidin resin were mixed together and incubated for $2 \mathrm{~h}$ at RT under constant rotation. After the incubation, the unspecific binding was reduced by washing the resin four times with buffer $\mathrm{A}$, four times with buffer B (0.1\% NP40, $1 \mathrm{M} \mathrm{NaCl}$ in PBS), twice with buffer $\mathrm{C}$ (0.1 $\mathrm{M}$ sodium carbonate in PBS, $\mathrm{pH} 11)$, and once with a solution of $\mathrm{NaCl}(0.5 \mathrm{M})$ in $\mathrm{PBS}(50 \mathrm{mM})$. The biotinylated proteins were eluted using $100 \mathrm{mM}$ DTT solution $\left(2 \times 30 \mathrm{~min}\right.$ at $\left.60^{\circ} \mathrm{C}\right)$, alkylated with $150 \mathrm{mM}$ iodoacetamide (30 min at RT in the dark) and finally precipitated with $20 \%$ trichloroacetic acid (overnight at $4{ }^{\circ} \mathrm{C}$ ). The protein pellet was washed twice with pure prechilled $\left(-20{ }^{\circ} \mathrm{C}\right)$ acetone and allowed to dry for $5 \mathrm{~min}$ at RT. Finally the pellet was dissolved in $50 \mu \mathrm{L}$ of $200 \mathrm{mM}$ ammonium bicarbonate buffer, and the $\mathrm{pH}$ was adjusted to 8.0 (with $100 \mathrm{mM} \mathrm{HCl}$ ). Protein concentration was determined using the BCA protein assay. For the mass spectrometry investigation, the dissolved proteins were digested with trypsin (Promega, Madison, WI, USA; porcine, sequencing grade, catalogue no. V551A; $1 / 50$, protease/protein) overnight at $37{ }^{\circ} \mathrm{C}$ followed by second digestion using fresh trypsin (1/ 100) for additional $4 \mathrm{~h}$. Prior to injection in the nanoHPLC system, a quantity corresponding to $5 \mu \mathrm{g}$ of peptides was desalted using ZipTip (Millipore, Billerca, MA, USA) according to the manufacturer's instructions. Subsequently, the peptides were lyophilized and dissolved in $20 \mu \mathrm{L}$ water containing $0.1 \%$ formic acid.

\section{Mass Spectrometry Analysis}

The peptide-containing samples were analyzed on the $2 \mathrm{D}$ nano-HPLC system Ultimate 3000 (Dionex, Sunnyvale, CA, USA) connected online to the electrospray ion-trap mass spectrometer Esquire HCT ultra (Bruker Daltonics, Bremen, Germany) as described previously. ${ }^{22}$ The acquired spectra were processed for peak-list generation using the Data Analysis software version 3.4 (Bruker Daltonics, Bremen, Germany). The peak-list files from all fractions were combined into one file for each individual animal and disease state. These combined files were submitted to the Swissprot database using the Mascot 
Table 1. Potentially Accessible Proteins Overexpressed in T98G and U373 Human Tumor Xenografts ${ }^{a}$

\begin{tabular}{|c|c|c|c|c|c|c|c|c|c|c|c|}
\hline \multirow[b]{2}{*}{ protein } & \multirow[b]{2}{*}{$\begin{array}{l}\text { accession } \\
\text { no. }\end{array}$} & \multicolumn{4}{|c|}{ normal brain } & \multicolumn{4}{|c|}{ tumor } & \multirow[b]{2}{*}{$\begin{array}{l}\text { ratio (tumor/ } \\
\text { normal) } \pm \mathrm{SD}\end{array}$} & \multirow[b]{2}{*}{$\begin{array}{r}\text { subcellular } \\
\text { localization }\end{array}$} \\
\hline & & $\begin{array}{c}\text { no. } \\
\text { normal }\end{array}$ & score & $\begin{array}{l}\text { no. unique } \\
\text { peptides }\end{array}$ & $\begin{array}{c}\text { sequence } \\
\text { coverage (\%) }\end{array}$ & $\begin{array}{l}\text { no. } \\
\text { tumor }\end{array}$ & score & $\begin{array}{l}\text { no. unique } \\
\text { peptides }\end{array}$ & $\begin{array}{c}\text { sequence } \\
\text { coverage (\%) }\end{array}$ & & \\
\hline \multicolumn{12}{|c|}{ T98G } \\
\hline \multicolumn{12}{|l|}{ mouse } \\
\hline SRC8 & Q60598 & 5 & 41 & 3 & 6 & 4 & 101 & 3 & 7 & $2.1 \pm 0.5$ & Сy; PM \\
\hline$\underline{\text { SPRL1 }}$ & $\underline{\text { P70663 }}$ & $\underline{4}$ & $\underline{46}$ & $\underline{\mathbf{3}}$ & $\underline{7}$ & $\underline{\mathbf{2}}$ & $\underline{61}$ & $\underline{4}$ & $\underline{9}$ & $\underline{2.5 \pm 0.1}$ & $\underline{\mathbf{S}}$ \\
\hline SC6A1 & P31648 & 1 & 62 & 1 & 4 & 3 & 57 & 2 & 4 & & PM; M \\
\hline APOE & P08226 & 1 & 65 & 3 & 15 & 3 & 59 & 2 & 8 & & S \\
\hline SAP & Q61207 & 1 & 154 & 6 & 13 & 3 & 62 & 2 & 5 & & $\mathrm{E}$ \\
\hline MRP & P28667 & n.d. & & & & 3 & 68 & 2 & 11 & & PM \\
\hline PICA & Q7M6Y3 & n.d. & & & & 3 & 108 & 3 & 5 & & $\mathrm{M}$ \\
\hline $\mathrm{TKT}$ & P40142 & n.d. & & & & 2 & 74 & 2 & 7 & & $\mathrm{U}$ \\
\hline ITB1 & P09055 & n.d. & & & & 1 & 87 & 6 & 9 & & $\mathrm{PM}$ \\
\hline \multicolumn{12}{|l|}{ human } \\
\hline POTEE & Q6S8J3 & n.d. & & & & 6 & 358 & 8 & 11 & & $\mathrm{U}$ \\
\hline CAC1S & Q13698 & n.d. & & & & 6 & 71 & 4 & 2 & & $\mathrm{M}$ \\
\hline OPCM & Q14982 & n.d. & & & & 5 & 156 & 2 & 11 & & $\mathrm{PM}$ \\
\hline GDS1 & P52306 & n.d. & & & & 5 & 104 & 3 & 5 & & $\mathrm{U}$ \\
\hline PTPRZ & P23471 & n.d. & & & & 4 & 174 & 3 & 2 & & $\mathrm{M}$ \\
\hline PCDH1 & Q08174 & n.d. & & & & 4 & 68 & 2 & 3 & & $\mathrm{PM}$ \\
\hline BOD1L & Q8NFC6 & n.d. & & & & 4 & 50 & 4 & 2 & & $\mathrm{U}$ \\
\hline S19A1 & $\mathrm{P} 41440$ & n.d. & & & & 3 & 36 & 2 & 2 & & $\mathrm{M}$ \\
\hline $\mathrm{DCD}$ & P81605 & n.d. & & & & 2 & 76 & 2 & 16 & & $S$ \\
\hline $\mathrm{HBD}$ & P02042 & n.d. & & & & 2 & 73 & 3 & 22 & & $\mathrm{E}$ \\
\hline FIBB & P02675 & n.d. & & & & 2 & 50 & 2 & 7 & & $S$ \\
\hline GNAI1 & P63096 & n.d. & & & & 2 & 70 & 3 & 8 & & PM; N; Cy \\
\hline \multicolumn{12}{|l|}{ common } \\
\hline $\mathrm{K} 2 \mathrm{C} 1$ & $\begin{array}{l}\text { P04264/ } \\
\text { P04104 }\end{array}$ & 6 & 122 & 4 & 6 & $6 / \underline{6}$ & $\begin{array}{l}159 / \\
\underline{791} \\
\end{array}$ & $4 / \underline{12}$ & $6 / \underline{22}$ & $\begin{array}{l}1.8 \pm 0.2 / \underline{5.8 \pm} \\
\underline{1.5}\end{array}$ & $\mathrm{PM}$ \\
\hline $\mathrm{K} 1 \mathrm{C} 13$ & $\begin{array}{l}\text { P13646/ } \\
\text { P08730 }\end{array}$ & 1 & 41 & 3 & 7 & $3 / \underline{3}$ & $\begin{array}{c}153 / \\
\underline{102} \\
\end{array}$ & $3 / \underline{4}$ & $8 / \underline{10}$ & & PM; Cy \\
\hline FXYD6 & $\begin{array}{l}\text { Q9H0Q3/ } \\
\text { Q9D164 }\end{array}$ & n.d. & & & & $3 / \underline{2}$ & $74 / \underline{51}$ & $1 / \underline{1}$ & $23 / \underline{23}$ & & M \\
\hline \multicolumn{12}{|c|}{ U373 } \\
\hline mouse & & & & & & & & & & & \\
\hline$\underline{S P R L 1}$ & $\underline{\text { P70663 }}$ & $\underline{4}$ & $\underline{46}$ & $\underline{3}$ & $\underline{7}$ & $\underline{2}$ & $\underline{72}$ & $\underline{4}$ & $\underline{8}$ & $\underline{2.0 \pm 0.0}$ & $\underline{\mathbf{S}}$ \\
\hline UBQL2 & Q9QZM0 & 1 & 89 & 1 & 3 & 3 & 76 & 2 & 3 & & M; N; Cy \\
\hline CLD11 & Q60771 & 1 & 83 & 1 & 7 & 3 & 89 & 1 & 7 & & $\mathrm{PM}$ \\
\hline PPM1H & Q3UYC0 & 1 & 44 & 2 & 5 & 3 & 49 & 2 & 4 & & $\mathrm{U}$ \\
\hline MAGI1 & Q6RHR9 & n.d. & & & & 2 & 54 & 4 & 3 & & PM; Cy \\
\hline ITB1 & P09055 & n.d. & & & & 1 & 48 & 3 & 4 & & $\mathrm{PM}$ \\
\hline \multicolumn{12}{|l|}{ human } \\
\hline GDS1 & P52306 & n.d. & & & & 6 & 89 & 3 & 7 & & $\mathrm{U}$ \\
\hline POTEE & Q6S8J3 & n.d. & & & & 5 & 485 & 6 & 9 & & $\mathrm{U}$ \\
\hline CAC1S & Q13698 & n.d. & & & & 5 & 68 & 4 & 2 & & $\mathrm{M}$ \\
\hline OPCM & Q14982 & n.d. & & & & 5 & 60 & 1 & 4 & & $\mathrm{PM}$ \\
\hline PCDH1 & Q08174 & n.d. & & & & 5 & 65 & 4 & 5 & & $\mathrm{PM}$ \\
\hline BOD1L & Q8NFC6 & n.d. & & & & 5 & 42 & 4 & 2 & & $\mathrm{U}$ \\
\hline PTPRZ & P23471 & n.d. & & & & 3 & 74 & 2 & 1 & & M \\
\hline $\mathrm{HBB}$ & P68871 & n.d. & & & & 3 & 122 & 3 & 24 & & $\mathrm{E}$ \\
\hline RCCD1 & A6NED2 & n.d. & & & & 3 & 48 & 1 & 3 & & $\mathrm{U}$ \\
\hline POTEI & P0CG38 & n.d. & & & & 3 & 112 & 4 & 5 & & $\mathrm{U}$ \\
\hline GNAI1 & P63096 & n.d. & & & & 2 & 62 & 2 & 7 & & PM; N; Cy \\
\hline AT2B3 & Q16720 & n.d. & & & & 2 & 168 & 4 & 4 & & $\mathrm{PM}$ \\
\hline AT2B1 & P20020 & n.d. & & & & 2 & 200 & 5 & 5 & & PM \\
\hline DLG2 & Q15700 & n.d. & & & & 2 & 55 & 5 & 8 & & $\mathrm{M} ; \mathrm{PM}$ \\
\hline S4A4 & Q9Y6R1 & n.d. & & & & 2 & 44 & 3 & 3 & & PM \\
\hline S12A4 & Q9UP95 & n.d. & & & & 2 & 47 & 5 & 5 & & $\mathrm{M}$ \\
\hline \multicolumn{12}{|l|}{ common } \\
\hline $\mathrm{K} 2 \mathrm{C} 1$ & $\begin{array}{l}\text { P04264/ } \\
\text { P04104 }\end{array}$ & 6 & 122 & 4 & 6 & $3 / \underline{6}$ & $\begin{array}{l}123 / \\
416 \\
\end{array}$ & $3 / \underline{9}$ & $5 / \underline{19}$ & $\begin{array}{l}0.73 \pm 0.1 / \underline{4.8} \\
\quad \pm 1.5\end{array}$ & $\mathrm{PM}$ \\
\hline
\end{tabular}


Table 1. continued

\begin{tabular}{|c|c|c|c|c|c|c|c|c|c|c|c|}
\hline \multirow[b]{2}{*}{ protein } & \multirow[b]{2}{*}{$\begin{array}{l}\text { accession } \\
\text { no. }\end{array}$} & \multicolumn{4}{|c|}{ normal brain } & \multicolumn{4}{|c|}{ tumor } & \multirow[b]{2}{*}{$\begin{array}{l}\text { ratio (tumor/ } \\
\text { normal) } \pm S D\end{array}$} & \multirow[b]{2}{*}{$\begin{array}{l}\text { subcellular } \\
\text { localization }\end{array}$} \\
\hline & & $\begin{array}{c}\text { no. } \\
\text { normal }\end{array}$ & score & $\begin{array}{l}\text { no. unique } \\
\text { peptides }\end{array}$ & $\begin{array}{c}\text { sequence } \\
\text { coverage }(\%)\end{array}$ & $\begin{array}{l}\text { no. } \\
\text { tumor }\end{array}$ & score & $\begin{array}{l}\text { no. unique } \\
\text { peptides }\end{array}$ & $\begin{array}{c}\text { sequence } \\
\text { coverage (\%) }\end{array}$ & & \\
\hline \multicolumn{12}{|c|}{ U373 } \\
\hline PICA & $\begin{array}{l}\text { Q13492/ } \\
\text { Q7M6Y3 }\end{array}$ & n.d. & & & & $3 / \underline{1}$ & $\begin{array}{c}109 / \\
117 \\
\end{array}$ & $3 / \underline{2}$ & $3 / \underline{3}$ & & M \\
\hline $2 \mathrm{ABB}$ & $\begin{array}{l}\text { Q00005/ } \\
\text { Q6ZWR4 }\end{array}$ & n.d. & & & & $2 / \underline{2}$ & $71 / \underline{71}$ & $2 / \underline{2}$ & $5 / \underline{5}$ & & PM; Cy \\
\hline RB43L & A6NDJ8 & n.d. & & & & $2 / \underline{2}$ & $77 / \underline{77}$ & $2 / \underline{2}$ & $15 / \underline{15}$ & & $\mathrm{U}$ \\
\hline F123A & $\begin{array}{l}\text { Q8N7J2/ } \\
\text { Q8CCJ4 }\end{array}$ & n.d. & & & & $2 / \underline{1}$ & $42 / \underline{45}$ & $2 / \underline{3}$ & $4 / \underline{5}$ & & $\mathrm{U}$ \\
\hline HXK3 & $\begin{array}{l}\text { P52790/ } \\
\text { Q3TRM8 }\end{array}$ & n.d. & & & & $1 / \underline{2}$ & $70 / \underline{63}$ & $3 / \underline{3}$ & $6 / \underline{4}$ & & $\mathrm{E} ; \mathrm{Cy}$ \\
\hline MRP & $\begin{array}{l}\text { P49006/ } \\
\text { P28667 }\end{array}$ & n.d. & & & & $1 / \underline{1}$ & $67 / \underline{67}$ & $2 / \underline{2}$ & $13 / \underline{13}$ & & PM \\
\hline
\end{tabular}

${ }^{a_{T}}$ The data are divided into three main groups: proteins confirmed as of (i) human origin and (ii) mouse origin and (iii) present both in human and mouse. In cases where the protein was identified both in normal and tumoral tissue, semi-quantitative protein quantification was conducted using the emPAI method (detailed in Material and Methods section). In the absence of emPAI (protein not found in the normal tissue), the number of biological replicates in which the respective protein was observed served as a semi-quantitative indicator of protein abundance (n.d. stands for not detected). Each individual protein hit was further characterized with the score (Mascot), the number of unique peptides found in the MS analysis, and the sequence coverage. When these parameters are reported for both species in the same column, the number in italics and underlined indicates the value for the human species. Uniprot database and Gene Ontology was used to infer the potential sub-cellular localization for each of the identified proteins. Following abbreviations are used: S, secreted; E, extracellular; PM, plasma membrane; Cy, cytoplasm; N, nucleus; M, membrane; and $U$, unknown. The quantification error is expressed as standard deviation of means (SD). Accession numbers refer to the Swiss-Prot database. Full protein names are outlined in the Supplemental Table S1.

search engine version 2.2.2 (Matrix Sciences, Boston, MA, USA). A homemade database (for details see below), consisting of the most recent (April, 2012) human and mouse protein entries was used (human number of entries $=20,225$; mouse number of entries $=16,539$; both obtained from Swissprot). The mass tolerances of precursor and fragmented ions were set at 0.6 and $0.3 \mathrm{Da}$, respectively; fixed modifications were carbamidomethyl; variable modification was oxidization of methionine; peptide charges were set at +2 and +3 . Trypsin cuts before proline and one missed cleavage were allowed. As far as the Mascot report parameters are concerned, the following formatting was used: significance threshold $=p<$ 0.05 , ions score cutoff $=30$, show subsets $=1$, require bold red $=$ unchecked. The false discovery rate (FDR) was calculated utilizing the "on flight" decoy function of the Mascot search engine.

Semi-quantitative analysis was performed for the proteins that were identified in both tumoral and normal samples and in more than two animals. The Mascot results yielded protein identifications along with the exponentially modified protein abundance index (emPAI). Ishihama et al. ${ }^{23}$ showed that the emPAI value is directly proportional to the protein quantity (for details see Supporting Information). Relative expression ratios were calculated from individual emPAI values (tumor/ normal). Mice homologue proteins found in the normal brain served as the reference when expression ratios were calculated for human proteins. This specific case occurred particularly when no discrimination of protein origin was possible ("common" proteins in the Table 1), and hence the pool of peptides used for the quantification of protein expression (between the two homologue proteins) had identical sequences. The normalization of protein expression ratios was conducted assuming a Gaussian distribution of the data (where the maximum number of the proteins has an relative expression ratio of 1.0). Proteins that were not eligible for emPAI quantification (not present in at least two animals) were screened for the frequency of presence or absence in all the samples. The proteins that were identified more frequently in the tumoral condition in comparison to the normal counterpart were also considered as potentially modulated.

\section{Determination of Protein Origin}

In the present experimental setup where human cells were xenografted in murine brain, a set of analysis was performed in order to discern the origin of all modulated proteins. Accordingly, all data sets were searched against a homemade database (DB), which consisted of both murine and human protein sequences. In this manner it was possible to distinguish three protein groups: (i) identified uniquely as mouse and (ii) identified as human, and those which (iii) were reported as both human and mouse. The latter group was the point of major interest, as it was important to determine if some of those proteins had peptides that were unique to the mouse or to human species. The analysis therefore consisted of examining the sequence coverage with respect to the mouse or human canonical protein sequence. Those proteins that displayed (i) more sequence coverage for the mouse sequence and had also (ii) unique peptides found only in mouse DB were considered as host produced (mouse) proteins. Conversely, proteins that displayed more sequence coverage for the human sequence and displayed unique peptides in human DB were attributed to human tumor cells. Differences in the amino acid sequence were confirmed by examining the MS/MS spectra. A peptide was considered unique for a given species if it contained a part of the sequence from non-homologous protein region. Modifications in single amino acids were not considered to be of a "unique character" as single nucleotide polymorphism might have contributed to such sequence variations.

\section{Validation of Protein Expression Using WB}

In order to validate the MS data indicating an overexpression of a particular protein, targeted WB analysis was employed. For this purpose brains of 3 normal, 3 U373, and 3 T98G animals were snap-frozen, converted into powder, and lysed with $1 \%$ 
SDS water solution containing protease inhibitors. Twenty micrograms of protein extracts were then heated for $5 \mathrm{~min}$ and separated by SDS-PAGE gel electrophoresis. Subsequently, the separated proteins were transferred onto PVDF membrane (Roche, Mannheim, Germany) at $30 \mathrm{~V}\left(4{ }^{\circ} \mathrm{C}\right)$ overnight. The membranes were blocked for $2 \mathrm{~h}$ at RT in TBS-T $(150 \mathrm{mM}$ $\mathrm{NaCl}, 100 \mathrm{mM}$ Tris, 0.1\% Tween-20, $\mathrm{pH}$ 7.5) containing 5\% nonfat dried milk (Biorad, Hercules, CA, USA). Subsequently, the membranes were incubated with diluted primary antibodies (anti-SPRL1, 1:500, cat. no. AF2728, R\&D systems, Minneapolis, MN, USA; anti-SAP, 1:1000, cat. no. 10801-1-AP, Proteintech, Manchester, U.K.; anti-ITB1, 1:500, cat. no. ab52971, Abcam, Cambridge, U.K.; anti-MRP, 1:500, cat. no. 11422-1-AP, Proteintech) for $2 \mathrm{~h}$ at RT. Following three TBS$\mathrm{T} 10$ min washes, the membranes were incubated for $1 \mathrm{~h}$ at RT with specific secondary antibody conjugated to horse radish peroxidase. The membranes were rinsed three times with TBS$\mathrm{T}$ followed by two washes with TBS. Finally, the immunoblots were visualized using ECL Western blotting substrate (Pierce). $\alpha$-Tubulin (TUBA) was used for normalization.

\section{Immunohistochemical Analysis of SPRL1 Protein}

The protein expression of SPRL1 was further studied using immunohistochemistry; the polyclonal anti-SPRL1 antibody was used at the dilution 1/50 (type and vendor as indicated above). The protein expression analysis was conducted on the tumor bearing mouse brain tissues (both U373 and T98G), human glioma (all grades), and normal brain tissues. In total, 4 animals per tumoral/normal condition as well as 23 glioblastoma, 8 astrocytoma grade III, 8 astrocytoma grade II, 7 astrocytoma grade I, and 5 normal adjacent tissues were evaluated.

The tissues were sliced from paraffin blocks ( $5 \mu \mathrm{m}$ sections), deparaffined 2 times in xylene for $5 \mathrm{~min}$, and hydrated in the methanol gradient (100\%, 95\%, 70\%, and 50\%). Blocking of unspecific peroxidase was performed for 30 min with $3 \% \mathrm{H}_{2} \mathrm{O}_{2}$ and $90 \%$ methanol. The incubation with the primary antibody was performed overnight at $4{ }^{\circ} \mathrm{C}$. The biotinylated secondary antibody was incubated initially for $30 \mathrm{~min}$ and subsequently with the avidin-biotin complex kit (ABC kit) for an additional 30 min. 3,3'-Diaminobenzidine tetrachlorhydrate dihydrate (DAB) with $5 \% \mathrm{H}_{2} \mathrm{O}_{2}$ was used for staining. The slides were counter-stained with hematoxylin.

Two neuropathology experts examined the tissue positivity independently. Evaluation of the antigen positivity was conducted for the intensity and the extent of the staining. The intensity value 0 denoted an undetectable staining, whereas 1, 2, or 3 denoted low, moderate, and strong immunoreactivity, respectively. Regarding the staining extent, values of $1,2,3$, or 4 denoted samples in which $\leq 25 \%, 26-50 \%, 51-75 \%$, or $76-$ $100 \%$ of the tissue showed immunoreactivity, correspondingly. The results obtained by these two scales were then multiplied together to yield a single value, named score. Following this, a ratio of tumoral versus normal brain was calculated. Statistical analyses and graphs were performed using Excel software (Microsoft, Redmond, WA, USA). Statistical significance of the antigen modulation was assessed using a two-tailed Student's $t$ test.

\section{RESULTS}

\section{Accessible Proteins Are Differentially Modulated in} Glioblastoma in Vivo

Using two different high grade in vivo glioma models (T98G and U373), the current proteomic study highlighted a distinct group of up-regulated and accessible proteins. The workflow of the study including the method used is outlined in Figure 1. Overall, 1081 and 1024 proteins were identified from the analysis of the T98G and U373 derived tumors, respectively (Figure 2). The mean FDR of the analysis (considering all

\section{T98G xenografts}

A
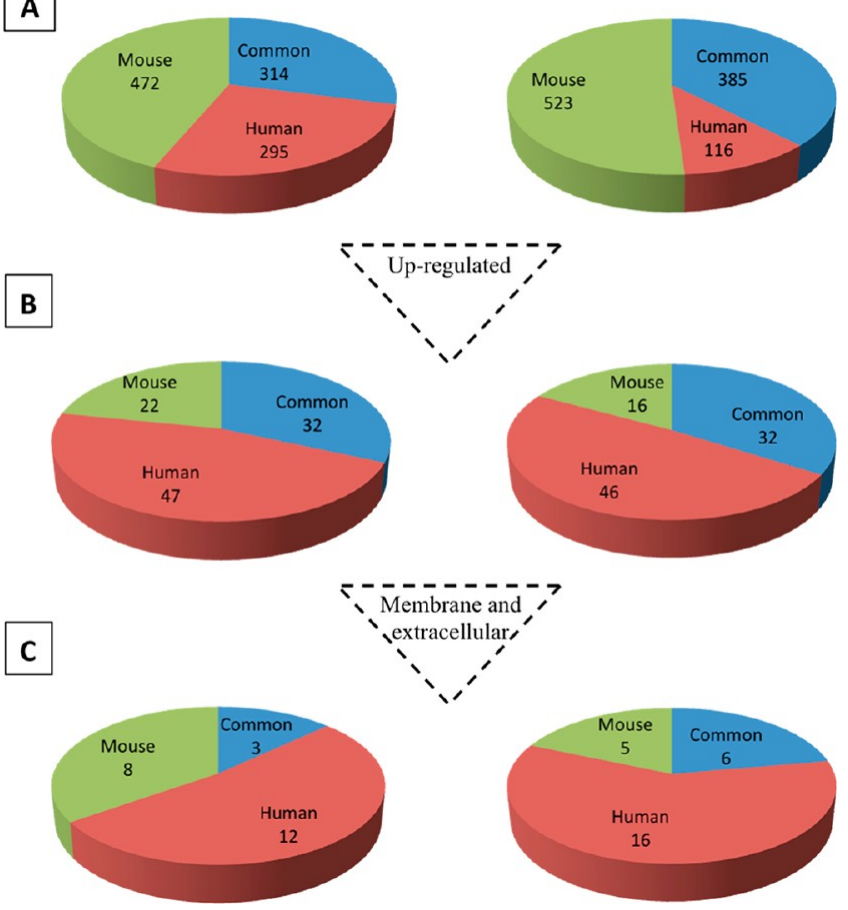

Figure 2. Overview of the identified proteins in two tumor models at different steps of analysis. The charts on the top (A) indicate the numbers of mouse, human, and undetermined proteins following the database search of MS/MS data. Below, chart B displays the number of up-regulated proteins following the comparison of each tumoral sample with the normal brain. Finally, chart $\mathrm{C}$ shows the percentage of up-regulated proteins that are potentially of accessible nature (Uniprot database).

samples) was $3.34 \%$ considering peptide matches above the identity threshold. Among the identified proteins three different groups were discernible: (i) human (27\% [T98G] and 11\% [U373]), (ii) mouse (44\% and 51\%), and (iii) a common set of proteins (29\% and 38\%) that could not be unambiguously assigned to either category (Figure $2 \mathrm{~A}$ ). Of all the proteins identified (in both models), one-tenth was up-regulated in the glioblastoma in comparison to the normal brain (Figure 2B). One-quarter of the up-regulated proteins were of membrane and extracellular origin (Figure 2C), and this group is displayed in Table 1. In the current study, a protein was considered as upregulated when the ratio of protein abundance (emPAI) between the tumoral and normal specimen exceeded the 2 -fold modulation or the protein was identified at least two times more often in the tumoral than in the normal condition. Proteins identified in only one tumoral condition were also 
included if they had at least 2 unique peptides. The subcellular localization of a given protein was determined on the basis of Gene Ontology or available literature information. Because of the specificity of the sample preparation method, proteins with currently unknown localization were included as well. These proteins are likely to be of extracellular and membrane origin and are hence treated as potentially accessible (Table 1).

SPRL1, SAP, ITB1, and MRP Are Confirmed as Overexpressed Proteins in Human Glioblastoma Model

Because little is known regarding their possible implication in high-grade gliomas, several proteins from Table 1 have attracted particular attention. Therefore, SPRL1, SAP, ITB1, and MRP were selected and further validated using WB analysis (Figure 3). This step was particularly important as some of the

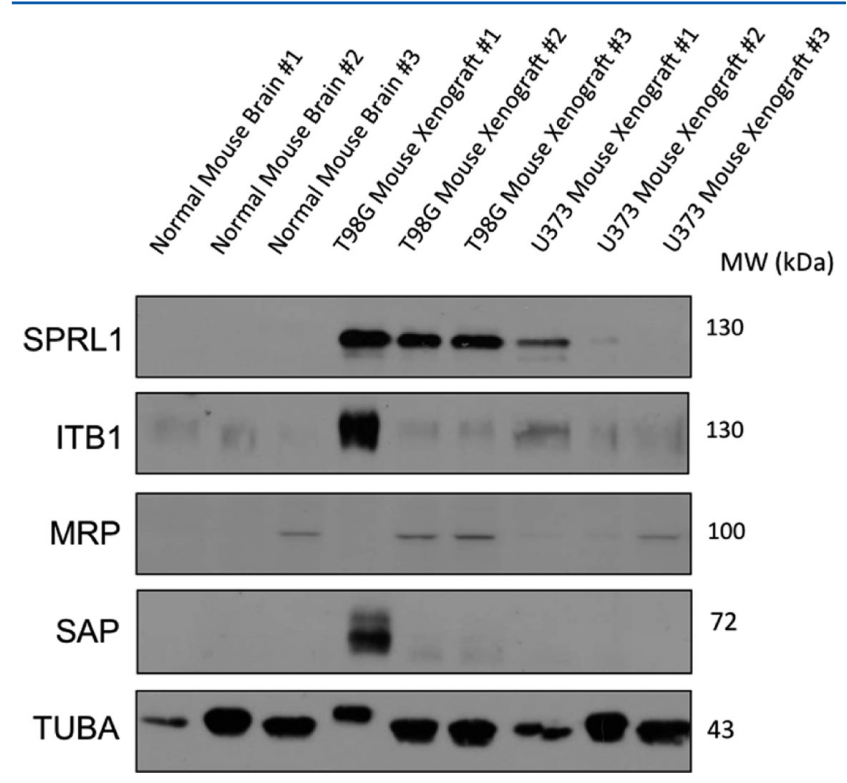

Figure 3. Western blot analysis of SPRL1, ITB1, MRP, and SAP protein expression in normal, T98G, and U373 xenografted mice brain. Three individual samples (animals) were used per condition. Normalization was conducted with $\alpha$-tubulin.

selected proteins (ITB1 and MRP) were identified only once in the MS analysis. As indicated in Figure 3, all proteins proved to be expressed in either of the glioma models, and except for MRP none was detected in the normal mouse brain. MRP was detected in one out of three normal brains. ITB1 and SAP were not detected in normal mice brain; however, they were found to be present in only one out of three T98G xenografts and absent in the U373 model (some faint bands of ITB1 in U373 were detected too). Notably only SPRL1 was validated as overexpressed in all three T98G and one U373 xenografts. However, MS analysis has identified SPRL1 in the normal mice brain too, and therefore it is to be assumed that this protein is expressed in the mice brain but at much lower concentration than in glioma.

\section{Glial Cells Overexpress SPRL1 in a Mouse Model of Human} Glioblastoma

In order to further investigate the expression of SPRL1 in the present glioblastoma mouse model, corresponding immunohistochemistry analysis was performed on paraffin fixed tissues (Figure 4C-E). The data indicated, in agreement with Western blot analysis, a strong overexpression of SPRL1 in both T98G and U373 mice gliomas. Staining in both tumor types displayed distinct cytoplasmatic positivity with some diffuse expression localized in the extracellular milieu. In normal mouse brain SPRL1 staining exhibited strong nuclear positivity in some neuronal cells; however, most of the cells were negative. In addition, IHC data suggests that SPRL1 is present in both normal and tumoral brains (in line with MS analysis); however, the types of cells expressing this protein (glial in the tumor and neuronal in the normal brain) as well as the amounts produced appear to be different.

SPRL1 Is Overexpressed in Human Glioma and Positively Correlates with the Tumor Grade

Following the confirmation of SPRL1 overexpression in the mouse model, additional IHC studies were directed towards evaluating the expression of this protein in human glioma samples. As shown in Figure 5A, a general increase of staining intensity is observed with evolving astrocytoma grade. In more detail, glial cells displayed medium to strong SPRL1 cytoplasmatic immunoreactivity (granular pattern) in glioblastomas and type III astrocytomas. The staining was of moderate to weak intensity in grade I and II astrocytomas and weak to negative in normal human brain. As far as the extensivenes of the staining is concerned, it can be stated that less than $25 \%$ of positive cells were detected in normal tissue and grade I and II astrocytomas, whereas more than $75 \%$ of cells were found to be reactive in grade III astrocytomas and glioblastomas. Occasionally, in glioblastomas, SPRL1 displayed moderate cytoplasmic immunoreactivity (diffuse pattern) in parallel to cytoplasmic expression in neoplastic blood vessels and normal endothelial cells (diffuse pattern) (Figure 5B). In normal positive tissue, SPRL1 also exhibited immunoreactivity in scattered endothelial cells (moderate cytoplasmic, diffuse pattern) and in few neuronal cells (strong cytoplasmic, granular pattern) (Figure $5 \mathrm{~B})$, similar to the observations made in mice glioma model.

Overall expression analysis confirmed the overexpression of SPRL1 in human gliomas, with statistical values supporting a significant correlation to increasing disease progression (Figure $5 \mathrm{C})$. Given the rather limited number of cases investigated in the current study, grade 4 (glioblastoma) was clearly distinguished from other glioma grades $(p \leq 0.05)$. This statistical strength can at least in part be attributed to a larger number of grade 4 cases involved in the current study $(N=23)$. Furthermore the IHC analysis could clearly highlight grade 3 gliomas as different from grade 1 and 4 . Statistical significance however decreased when grade 1 and 2 as well as 2 and 3 were compared. In this case, the number of cases being analyzed could be considered as one of the limiting factors $(N=8$ [for grade 2 and 3] and $N=7$ [for grade 1]) to demonstrate the statistical significance of SPRL1 expression and to distinguish between different degrees of disease progression.

\section{DISCUSSION}

The specific experimental setup, where human cancer cells are xenografted in mouse model (here brain), was employed in the past with other tumor models ${ }^{24-30}$ and offered in the current study the potential to distinguish the modulated proteins by their origin (host versus tumor). Mass-spectrometry-based high-throughput peptide sequencing enabled to a certain degree sorting between human and mouse protein fragments. In some cases of proteins that are highly conserved between the two species, the protein origin could not be clearly distinguished. Apart from these obvious limitations, characterizing host response for gliomas is particularly difficult since 

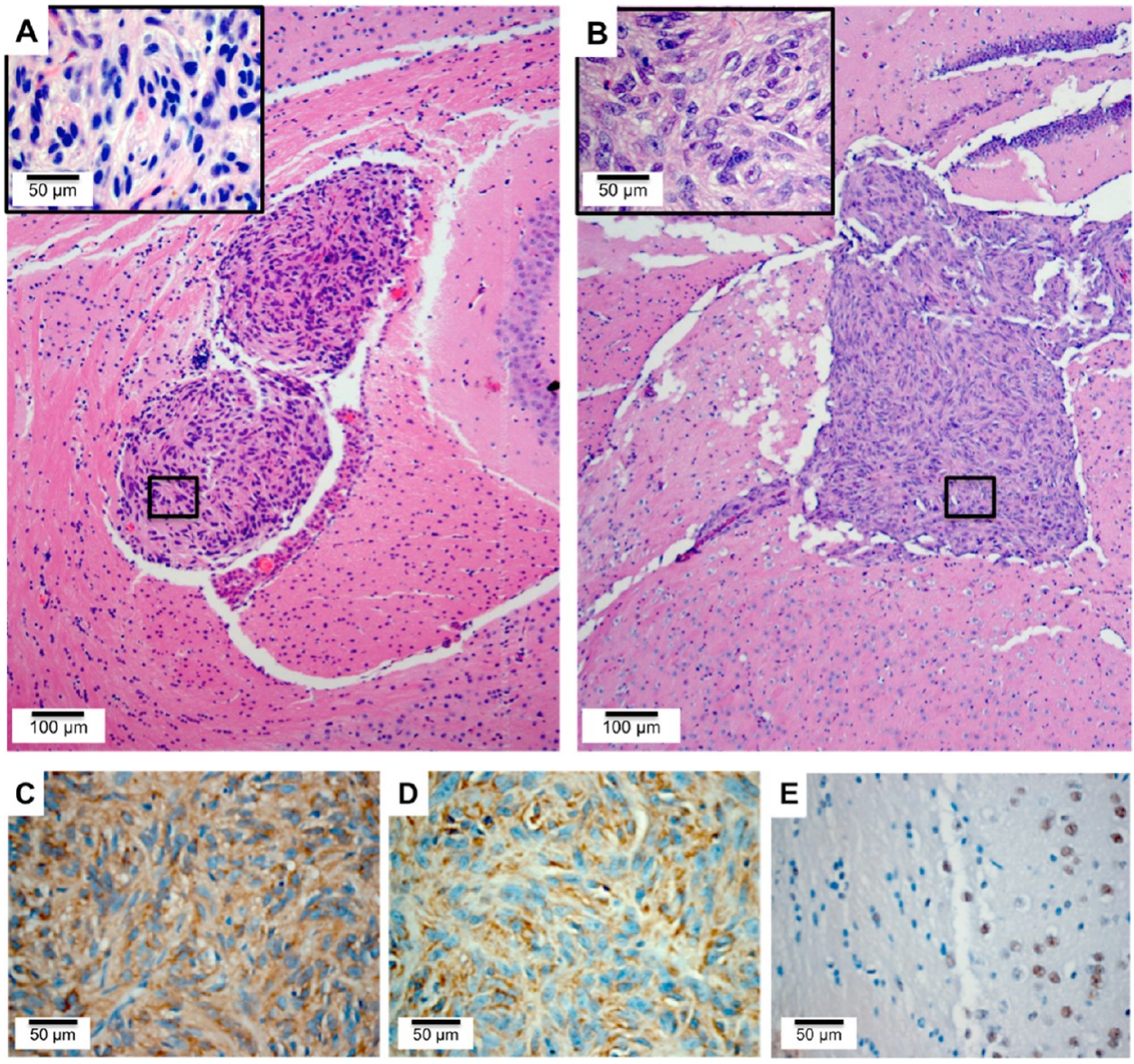

Figure 4. (A-E) Histological evaluation of T98G and U373 tumors. Hematoxylin \& eosin staining of T98G and U373 mouse brain xenografts (A, B). Magnification 200X. Both images include a magnified (400X) portion of the tumor (top left corner). Immunohistochemical analysis of SPRL1 protein expression in normal mouse and xenografted brain (C-E). Strong positivity was detectable in both T98G (C) and U373 (D) mouse brain xenografts. SPRL1 expression was generally negative in normal mouse brain, apart from distinct positivity that was observable in some glial cells (E). Magnification 400X. All images are representative of 3 independent histological evaluations.

these tumors arise from glial cells, which under normal circumstances constitute the brain's supportive matrix. However, proteins arising from the host reaction are likely to be more stable than the one produced by the genetically evolving glioma cells and hence could be more suitable as efficient targets for therapy applications. Therefore in gliomas it is challenging to tell apart proteins that originate from (or are differentially expressed in) "normal" versus tumoral glial cells. However, the strategy applied in the current study proved to be an appropriate tool for providing information on host vs tumoral response.

Proteins that are of interest for targeted therapies or imaging technologies require to be deposited/immobilized in the tumor tissue and should not be systemically distributed. We therefore chose to specifically focus on exactly this group proteins, employing a previously published ex vivo tissue biotinylation approach. ${ }^{19,20}$ Overall, in the current study over 1000 proteins were identified and quantified in both cell lines, of which twothirds were assigned to either human or mouse species. Of the identified proteins, $\sim$ one-half was assigned to mouse and $\sim$ onequarter to human origin depicting the skewed ratio of normal (mouse) to tumoral (human) cells. In order words, the tumoral mass is clearly underrepresented in the xenografted brains, and this is also confirmed in corresponding histological analysis (Figure 4A and B). Certainly, bringing this ratio to a more equal level would improve the analysis, providing equal analytical coverage to both tumor and host tissue. One possible way could be the microdissection of the tissue; however, current proteomic methods are challenged with handling such minute protein amounts. Interestingly, as the analysis moved toward extracting only targets with up-regulated expression, considerably more human ( one-half) then mouse ( onequarter) proteins were highlighted. This finding could possibly indicate that the reactive host tissue is "diluted" in the "nonreactive" remaining normal brain. In this way, a significant part of modulated host proteins could remain unidentifiable. Aiming to uncover this concealed group of proteins could help further characterize the host response in cancer.

Following mass spectrometry analysis, including subsequent IHC and Western blot validation steps, SPRL1 (also known as hevin) appeared particularly interesting for further studies in human glioma samples. This protein has been found previously to be expressed in the extracellular matrix of many normal human tissues. ${ }^{31}$ We conducted an additional in silico survey based on the Gene Cards database (http://www.genecards. org), which confirmed this observation. This database compiles information on mRNA expression in a total of 23 different normal human tissues hybridized against the Affymetrix HGU95A-E and HG-U133A DNA-microarrays, respectively. ${ }^{32}$ The results are presented in the Supporting Information (Figure S1), indicating that SPRL1 has probably an important physiological role. To this end, literature shows that SPRL1 is 
A
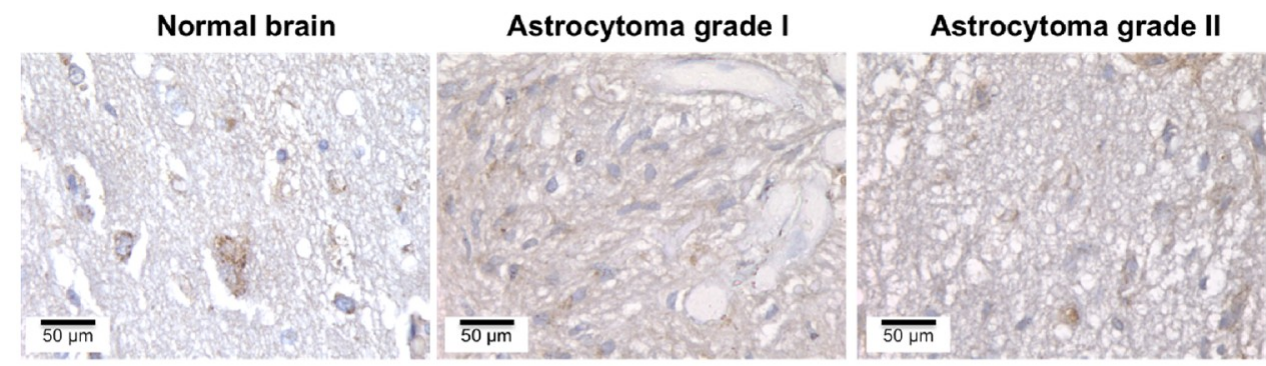

Astrocytoma grade III

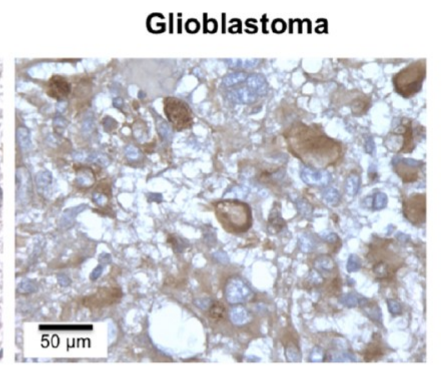

B
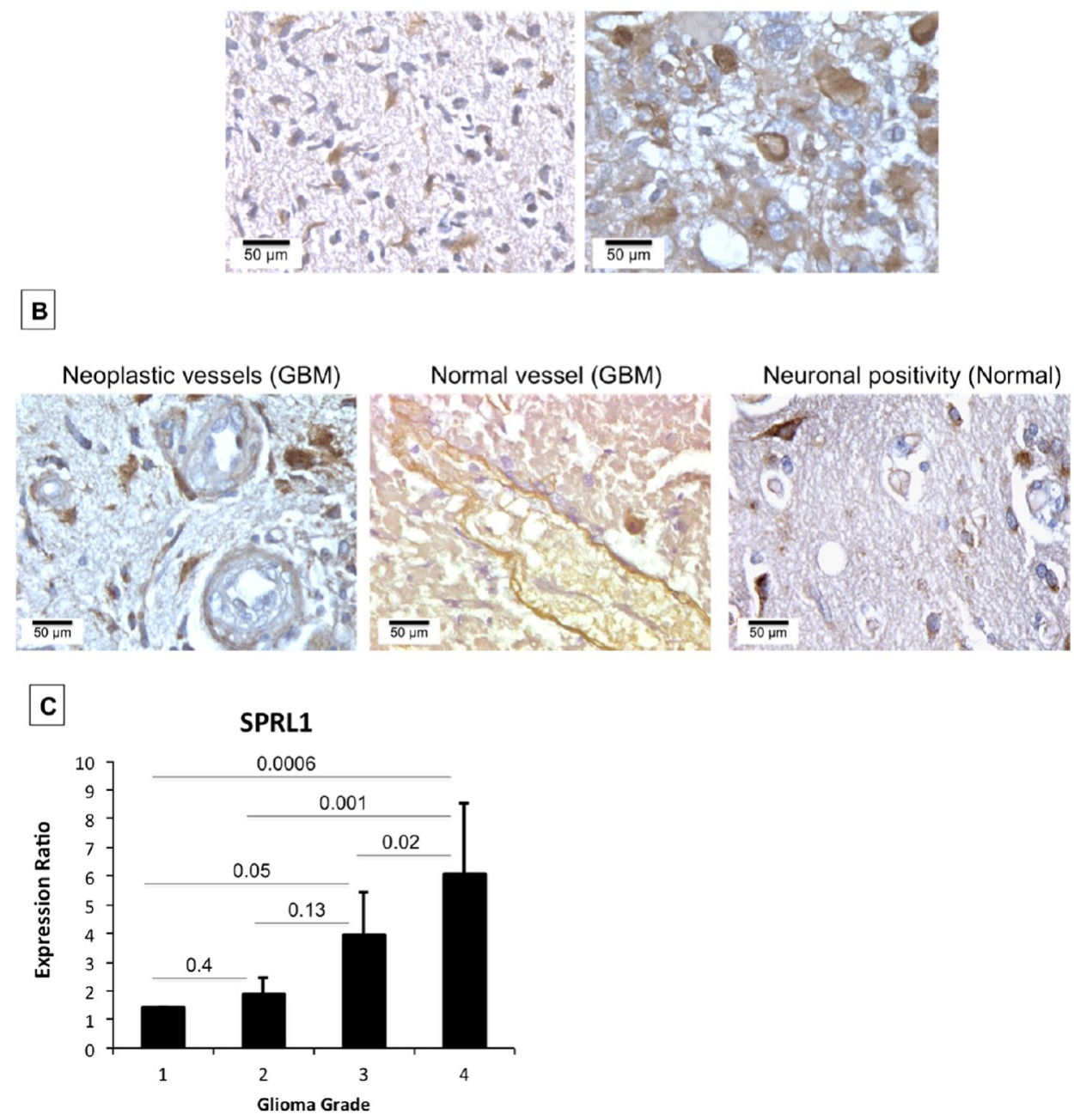

Figure 5. (A-C) Immunohistochemical analysis of sparc like-1 (SPRL1) protein expression including statistical evaluation. Panel A shows SPRL1 expression in normal brain, followed by astrocytoma grade I to III and glioblastoma (astrocytoma grade IV). Distinct staining patterns in the neoplastic and normal vessels of the glioblastoma samples as well as SPRL1 staining in the neurons of the normal tissue are shown in panel B. Images are displayed at 400x magnification and are representative of respective biological replicates (as indicated in Materials and Methods). Statistical evaluation of relative protein expression (normalized to normal human brain) indicates a partially significant trend (not significant [at $p \leq 0.05$ ] between grades 1 and 2 as well as 2 and 3; significant [at $p \leq 0.05$ ] between grades 1 and 4; 1 and 3, 4, and 2; as well as 3 and 4 ) of increasing SPRL1 expression with the glioma grade $(\mathrm{C})$.

expressed on the basal, lateral, and apical surfaces of endothelial cells but not at the basement membrane. ${ }^{33}$ From a functional point of view SPRL1 inhibits attachment and spreading of endothelial cells to fibronectin (in vitro), preventing these from forming focal adhesions. ${ }^{33}$ SPRL1 is also known to bind collagen $-\mathrm{I}^{34}$ and can regulate decorin production and collagen assembly. $^{35}$
In cancer, the role of SPRL1 remains poorly understood. Of the studies examining the expression of SPRL1 in tumor, downregulation of this protein was reported in metastatic prostate adenocarcinoma, ${ }^{36}$ non-small cell lung cancer, ${ }^{37}$ and gastric cancer. ${ }^{38}$ Notably, in the study of $\mathrm{Li}$ and colleagues, SPRL1 positive patients exhibited a better median survival than SPRL1negative patients. Up-regulation of SPRL1 was observed in 
pancreatic cancer, ${ }^{39}$ colorectal adenocarcinomas, ${ }^{40}$ and hepatocellular cancer. ${ }^{41}$ Due to this apparent evidence of both upand down-regulation of this protein in cancer, SPRL1 will probably assume different roles in different types of malignancies. In the context of glioma, the study of Lau et al. is particularly interesting as the authors observed that SPRL1 expression correlates with tumor angiogenesis. ${ }^{41}$ One of the most important features of glioblastoma, in comparison to the lower grade gliomas, is the appearance of prominent angiogenesis. New vessels supply critical nutrients required for the aggressive growth of these glial tumors. The current study fits another piece of the puzzle as it demonstrates that increasing SPRL1 expression accompanies glioma progression from low to high grades. Therefore, one of the key hypotheses to test in future work would concern the putative pro-angiogenic function of SPRL1 in human glioblastoma. Finally, another aspect of SPRL1 that may prove interesting concerns the protein's striking homology with SPARC (over 50\% of amino acid sequence is shared). SPARC (also referred to as osteonectin) is known to be anti-adhesive and is implicated in cancer in G1 to $S$ phase cell cycle progression, regulation of extracellular matrix via metalloproteinases, and interaction with platelet-derived and vascular endothelial growth factors. ${ }^{42}$ Previously our group has reported high SPARC levels in breast cancer. ${ }^{43}$ Taken together, it is not unreasonable to assume that the function of sparc-like protein 1 is important in the physiological and pathophysiological process in a similar fashion to the homologue SPARC. This further hypothesis merits additional studies regarding the precise function of SPRL1 in human cancer.

\section{ASSOCIATED CONTENT}

\section{S Supporting Information}

This material is available free of charge via the Internet at http://pubs.acs.org.

\section{AUTHOR INFORMATION}

\section{Corresponding Author}

*E-mail: a.turtoi@ulg.ac.be.

Notes

The authors declare no competing financial interest.

\section{ACKNOWLEDGMENTS}

The authors acknowledge the support of GIGA-Proteomics Platform of the ULG for experimental support and Dr. Bruno Dumont for his assistance with data evaluation. This work was supported by a grant from the Research Concerted Action (IDEA project) of the University of Liège (ULG), Belgium, from the CEE (FP7 network: ADAMANT-Antibody Derivatives As Molecular Agents for Neoplastic Targeting (HEALTHF2-2007-201342)), from the National Fund for Scientific Research (NFSR, Belgium) and TELEVIE as well as from the Centre Anti-Cancéreux of the ULG.

\section{REFERENCES}

(1) Jessen, K. R. Glial cells. Int. J. Biochem. Cell Biol. 2004, 36 (10), 1861-7.

(2) Nieto-Sampedro, M; Saneto, R. P.; de Vellis, J; Cotman, C. W. The control of glial populations in brain: changes in astrocyte mitogenic and morphogenic factors in response to injury. Brain Res. 1985, 343 (2), 320-8.
(3) Nistér, M; Uhrbom, L; Hesselager, G; Westermark, B. Glial tumors of the CNS. In Glial Cell Development: Basic Principles and Clinical Relevance, 2nd ed.; Jessen, K. R.; Richardson, W. D., Eds.; Oxford University Press: Oxford, 2001; pp 437-456.

(4) Louis, D. N.; Ohgaki, H; Wiestler, O. D.; Cavenee, W. K.; Burger, P. C.; Jouvet., A; Scheithauer, B. W.; Kleihues, P. The 2007 WHO classification of tumours of the central nervous system. Acta Neuropathol. 2007, 114 (2), 97-109.

(5) Stupp, R; Mason, W. P.; van den Bent, M. J.; Weller, M; Fisher., B; Taphoorn, M. J.; Belanger, K.; Brandes, A. A.; Marosi, C; Bogdahn, U; Curschmann, J; Janzer, R. C.; Ludwin, S. K.; Gorlia, T; Allgeier, A; Lacombe, D; Cairncross, J. G.; Eisenhauer, E; Mirimanoff, R. O. European Organisation for Research and Treatment of Cancer Brain Tumor and Radiotherapy Groups; National Cancer Institute of Canada Clinical Trials Group. Radiotherapy plus concomitant and adjuvant Temozolomide for glioblastoma. N. Engl. J. Med. 2005, 352 (10), 987-96.

(6) Iacob, G; Dinca, E. B. Current data and strategy in glioblastoma multiforme. J. Med. Life 2009, 2 (4), 386-93.

(7) Ohgaki, H. Epidemiology of brain tumors. Methods Mol. Biol. 2009, 472, 323-42.

(8) Alves, T. R.; Lima, F. R.; Kahn., S. A.; Lobo, D; Dubois, L. G.; Soletti., R; Borges, H; Neto, V. M. Glioblastoma cells: a heterogeneous and fatal tumor interacting with the parenchyma. Life Sci. 2011, 89 (15-16), 532-9.

(9) Omuro, A. M.; Faivre, S; Raymond, E. Lessons learned in the development of targeted therapy for malignant gliomas. Mol. Cancer Ther. 2007, 6 (7), 1909-19.

(10) Hegi, M. E.; Diserens, A. C.; Bady, P; Kamoshima, Y; Kouwenhoven, M. C.; Delorenzi, M; Lambiv, W. L.; Hamou, M. F.; Matter, M. S.; Koch, A; Heppner, F. L.; Yonekawa, Y; Merlo, A; Frei, K; Mariani, L; Hofer, S. Pathway analysis of glioblastoma tissue after preoperative treatment with the EGFR tyrosine kinase inhibitor gefitinib-a phase II trial. Mol. Cancer Ther. 2011, 10 (6), 1102-12.

(11) Iwamoto, F. M.; Lamborn, K. R.; Robins, H. I.; Mehta, M. P.; Chang, S. M.; Butowski, N. A.; Deangelis, L. M.; Abrey, L. E.; Zhang, W. T.; Prados, M. D.; Fine, H. A. Phase II trial of pazopanib (GW786034), an oral multi-targeted angiogenesis inhibitor, for adults with recurrent glioblastoma (North American Brain Tumor Consortium Study 06-02). Neuro-Oncol. 2010, 12 (8), 855-61.

(12) Razis, E; Selviaridis, P; Labropoulos, S; Norris, J. L.; Zhu, M. J.; Song, D. D.; Kalebic, T; Torrens, M.; Kalogera-Fountzila, A; Karkavelas, G; Karanastasi, S; Fletcher, J. A.; Fountzilas, G. Phase II study of neoadjuvant imatinib in glioblastoma: evaluation of clinical and molecular effects of the treatment. Clin. Cancer Res. 2010, 15 (19), $6258-66$.

(13) Lu, P; Weaver, V. M.; Werb., Z. The extracellular matrix: a dynamic niche in cancer progression. J. Cell Biol. 2012, 196 (4), 395406.

(14) Branle, F; Lefranc, F; Camby, I; Jeuken, J; Geurts-Moespot, A; Sprenger, S; Sweep, F; Kiss, R; Salmon, I. Evaluation of the efficiency of chemotherapy in in vivo orthotopic models of human glioma cells with and without $1 \mathrm{p} 19 \mathrm{q}$ deletions and in C6 rat orthotopic allografts serving for the evaluation of surgery combined with chemotherapy. Cancer 2002, 95 (3), 641-55.

(15) Karmakar, S; Banik, N. L.; Patel, S. J; Ray, S. K. Combination of all-trans retinoic acid and taxol regressed glioblastoma T98G xenografts in nude mice. Apoptosis 2007, 12 (11), 2077-87.

(16) Deng, L; Li, G; Li, R; Liu, Q; He, Q; Zhang, J Rho-kinase inhibitor, fasudil, suppresses glioblastoma cell line progression in vitro and in vivo. Cancer Biol. Ther. 2010, 9 (11), 875-84.

(17) De Ridder, L. I.; Laerum., O. D.; Mork., S. J.; Bigner, D. D. Invasiveness of human glioma cell ines in vitro: relation to tumorigenicity in athymic mice. Acta Neuropatol. 1987, 72 (3), 207-13.

(18) Stein, G. H. T98G: an anchorage independent human tumor cell ine that exhibits stationary phase G1 arrest in vitro. J. Cell Physiol. 1979, 99 (1), 43-54. 
(19) Castronovo, V; Kischel, P; Guillonneau, F; de Leval, L; Deféchereux, T; De Pauw, E; Neri, D; Waltregny., D. Identification of specific reachable molecular targets in human breast cancer using a versatile ex vivo proteomic method. Proteomics 2007, 7 (8), 1188-96.

(20) Conrotto, P; Roesli, C; Rybak, J; Kischel, P; Waltregny, D; Neri, $\mathrm{D}$; Castronovo, V. Identification of new accessible tumor antigens in human colon cancer by ex vivo protein biotinylation and comparative mass spectrometry analysis. Int. J. Cancer. 2008, 123 (12), 2856-64.

(21) Belot, N; Rorive, S; Doyen, I; Lefranc, F; Bruyneel, E; De Decker, R; Micik, S; Brotchi, J; Decaestecker, C; Salmon, I; Kiss, R; Camby, I. Molecular characterization of cell-substratum attachments in human glial tumors relates to prognostic features. Glia 2001, 36, 375390.

(22) Turtoi, A; Musmeci, D; Wang, Y; Dumont, B; Somja, J; Bevilacqua, G; De Pauw, E; Delvenne, P; Castronovo, V. Identification of novel accessible proteins bearing diagnostic and therapeutic potential in human pancreatic ductal adenocarcinoma. J. Proteome Res. 2011, 10 (9), 4302-13.

(23) Ishihama, Y; Oda, Y; Tabata, T; Sato, T; Nagasu, T; Rappsilber, J; Mann, M. Exponentially modified protein abundance index (emPAI) for estimation of absolute protein amount in proteomics by the number of sequenced peptides per protein. Mol. Cell. Proteomics 2008, 4 (9), 1265-1272.

(24) Pitteri, S. J.; Faca, V. M.; Kelly-Spratt, K. S.; Kasarda, A. E.; Wang, H; Zhang, Q; Newcomb, L; Krasnoselsky, A; Paczesny, S.; Choi, G; Fitzgibbon, M; McIntosh, M. W.; Kemp, C. J.; Hanash, S. M. Plasma proteome profiling of a mouse model of breast cancer identifies a set of up-regulated proteins in common with human breast cancer cells. J. Proteome Res. 2008, 7 (4), 1481-9.

(25) Orazine, C. I.; Hincapie, M.; Hancock, W. S.; Hattersley, M.; Hanke, J. H. A proteomic analysis of the plasma glycoproteins of a MCF-7 mouse xenograft: a model system for the detection of tumor markers. J. Proteome Res. 2008, 7 (4), 1542-54.

(26) Pitteri, S. J.; JeBailey, L.; Faça, V. M.; Thorpe, J. D.; Silva, M. A.; Ireton, R. C.; Horton, M. B.; Wang, H; Pruitt, L. C.; Zhang, Q; Cheng, K. H.; Urban, N; Hanash, S. M.; Dinulescu, D. M. Integrated proteomic analysis of human cancer cells and plasma from tumor bearing mice for ovarian cancer biomarker discovery. PLoS One 2009, 4 (11), e7916

(27) Bijian, K.; Mlynarek, A. M.; Balys, R. L.; Jie, S.; Xu, Y.; Hier, M. P.; Black, M. J.; Di Falco, M. R.; LaBoissiere, S.; Alaoui-Jamali, M. A. Serum proteomic approach for the identification of serum biomarkers contributed by oral squamous cell carcinoma and host tissue microenvironment. J. Proteome Res. 2009, 8 (5), 2173-85.

(28) Kuick, R.; Misek, D. E.; Monsma, D. J.; Webb, C. P.; Wang, H.; Peterson, K. J.; Pisano, M.; Omenn, G. S.; Hanash, S. M. Discovery of cancer biomarkers through the use of mouse models. Cancer Lett. 2007, 249 (1), 40-8.

(29) Wu, C. C.; Peng, P. H.; Chang, Y. T.; Huang, Y. S.; Chang, K. P.; Hao, S. P.; Tsang, N. M.; Yeh, C. T.; Chang, Y,S.; Yu, J. S. Identification of potential serum markers for nasopharyngeal carcinoma from a xenografted mouse model using Cy-dye labeling combined with three-dimensional fractionation. Proteomics 2008, 8 (17), 3605-20.

(30) Van den Bemd, G. J.; Krijgsveld, J.; Luider, T. M.; van Rijswijk, A. L.; Demmers, J. A.; Jenster, G. Mass spectrometric identification of human prostate cancer-derived proteins in serum of xenograft-bearing mice. Mol. Cell. Proteomics 2006, 5 (10), 1830-9.

(31) Claeskens, A; Ongenae, N; Neefs, J. M.; Cheyns, P; Kaijen, P; Cools, M; Kutoh, E. Hevin is down-regulated in many cancers and is a negative regulator of cell growth and proliferation. Br. J. Cancer. 2000, $82,1123-1130$.

(32) Safran, M; Chalifa-Caspi, V; Shmueli, O; Olender, T; Lapidot, M; Rosen, N; Shmoish, M; Peter., Y; Glusman, G; Feldmesser, E; Adato, A; Peter, I; Khen, M; Atarot, T; Groner, Y; Lancet, D. Human gene-centric databases at the Weizmann institute of science: GeneCards, UDB, CroW 21 and HORDE. Nucleic Acids Res. 2003, 31 (1), 142-6.
(33) Girard, J. P.; Springer, T. A. Modulation of endothelial cell adhesion by hevin, an acidic protein associated with high endothelial venules. J. Biol. Chem. 1996, 271 (8), 4511-7.

(34) Hambrock, H. O.; Nitsche, D. P.; Hansen, U; Bruckner, P; Paulsson, M; Maurer, P; Hartmann, U. SC1/hevin. An extracellular calcium-modulated protein that binds collagen I. J. Biol. Chem. 2003, 278 (13), 11351-8.

(35) Sullivan, M. M.; Sage, E. H. Hevin/SC1, a matricellular glycoprotein and potential tumor sppressor of the SPARC/BM-40/ Osteonectin family. Int. J. Biochem. Cell Biol. 2004, 36 (6), 991-6.

(36) Nelson, P. S.; Plymate, S. R.; Wang, K; True, L. D.; Ware, J. L.; Gan, L; Liu, A. Y.; Hood, L. Hevin, an antiadhesive extracellular matrix protein, is down-regulated in metastatic prostate adenocarcinoma. Cancer Res. 1998, 58 (2), 232-6.

(37) Bendik, I; Schraml, P; Ludwig, C. U. Characterization of MAST9/Hevin, a SPARC-like protein, that is down-regulated in nonsmall cell lung cancer. Cancer Res. 1998, 58 (4), 626-9.

(38) Li, P; Qian, J; Yu, G; Chen, Y; Liu, K; Li, J; Wang, J. Downregulated SPARCL1 is associated with clinical significance in human gastric cancer. J. Surg. Oncol. 2012, 105 (1), 31-7.

(39) Esposito, I; Kayed, H; Keleg, S; Giese, T; Sage, E. H.; Schirmacher, P; Friess, H; Kleeff, J. Tumor-suppressor function of SPARC-like protein 1/Hevin in pancreatic cancer. Neoplasia 2007, 9 (1), 8-17.

(40) Zhang, H; Widegren, E; Wang, D. W.; Sun, X. F. SPARCL1: a potential molecule associated with tumor diagnosis, progression and prognosis of colorectal cancer. Tumour Biol. 2011, 32 (6), 1225-31.

(41) Lau, C. P.; Poon, R. T.; Cheung, S. T.; Yu, W. C.; Fan, S. T. SPARC and Hevin expression correlate with tumour angiogenesis in hepatocellular carcinoma. J. Pathol. 2006, 210 (4), 459-68.

(42) Tai, I. T.; Tang, M. J. SPARC in cancer biology: its role in cancer progression and potential for therapy. Drug Resist. Updates 2008, 11 (6), 231-46.

(43) Bellahcène, A; Castronovo, V. Increased expression of osteonectin and osteopontin, two bonematrix proteins, in human breast cancer. Am. J. Pathol. 1995, 146 (1), 95-100. 